\title{
Research on the influence of steel slag powder, slag power, and fly ash on the performance of concrete
}

\author{
Kaiqiang Song ${ }^{1, a}$, Futian Liu $^{1, b}$ \\ ${ }^{1}$ School of Materials Science and Engineering, University of Jinan, Jinan 250022, China \\ a240830115@qq.com, ${ }^{\text {b } 424425997 @ q q . c o m ~}$
}

Keywords: Composite admixture, performance, mechanical properties, hydration, excitation.

\begin{abstract}
In this paper, steel slag powder, slag powder and fly ash mixed with different proportions, equivalent replacement of cement, as concrete admixture, study the effect of the admixture on the performance and mechanical properties of concrete, and through the XRD, SEM, differential thermal and other micro testing means, discusses its hydration characteristic. The results show that: when the total amount of the admixture is less than $40 \%$, the increase of its total content is beneficial to improve the working performance and mechanical properties of concrete, and the best ratio is steel slag powder: slag power: fly ash =1:2:1. The results of the study have found that the hydration products of the cementitious materials are the same as that of the pure cement. Early, cementitious materials activity are low, but later, under $\mathrm{Ca}(\mathrm{OH})_{2}$ excitation, cementitious materials began to hydrolysis, produce hydrated calcium silicate, hydrated calcium aluminate, and the hardened paste structure is more dense.
\end{abstract}

\section{Introduction}

With the development of modern cement concrete technology, mineral admixture has become an essential component of concrete. Slag and fly ash are two kinds of common concrete admixture, which can not only save the cement dosage, reduce the cost of concrete production, reduce energy consumption, but also improve the performance of concrete, mechanical properties, and improve the durability of concrete. At present, the industry has a more in-depth study on the performance of the fly ash and slag [1-3], engineering application is also more extensive, but the steel slag powder, slag powder and fly ash three mixed as a concrete composite admixture of research is not much.

Steel slag is a by-product in the process of steel making. China's annual steel output is about 20000 million tons, the annual emissions of steel slag reached more than 1600 million tons, but the utilization rate of steel slag is only about $10 \%$. Steel slag contains a certain amount of cement clinker mineral $\mathrm{C}_{3} \mathrm{~S}, \mathrm{C}_{2} \mathrm{~S}$, etc., therefore, it has the conditions for the admixture of concrete [4]. When steel slag powder and slag powder and fly ash are mixed in concrete compound admixture, the three are activated, for the preparation of green high performance concrete provides convenient conditions, but also can realize the steel slag, slag, fly ash resources and high value of comprehensive utilization.

\section{Experimental}

\section{Experimental Material.}

The test using P.O 42.5 cement from Shandong Lubi, steel slag powder, slag powder, fly ash are produced in Laiwu steel. The main chemical compositions and physical properties of the test raw materials are shown in table 1 . Figure 1 shows the $\mathrm{X}$ - ray diffraction spectra (XRD) of steel slag powder, and by the spectra, we can find $\mathrm{C}_{2} \mathrm{~S}, \mathrm{C}_{3} \mathrm{~S}, \mathrm{C}_{2} \mathrm{~F}, \mathrm{RO}$ phase $(\mathrm{MgO}, \mathrm{FeO}$ and $\mathrm{MnO}$ solid solution), merwinite, etc. Figure 2 shows the scanning electron microscope photos of steel slag powder, which can be seen from the picture, the steel slag powder particles are irregular polyhedron shape, and most of the particle size is less than $20 \mu \mathrm{m}$.

Fine aggregate using river sand, fineness modulus is 3.10; Coarse aggregate used by limestone, with $4.75 \sim 26.5 \mathrm{~mm}$ continuous gradation, among them $4.75 \sim 9.5 \mathrm{~mm}, 9.5 \sim 16 \mathrm{~mm}, 16 \sim 26.5 \mathrm{~mm}$ 
were $25 \%$, 35\%, 40\%, respectively. Superplasticizer is naphthalene compound water reducing agent, water reducing rate is $25 \%$, compositions are shown in Table 2.

Table 1 chemical composition and physical properties of main raw materials

\begin{tabular}{|c|c|c|c|c|c|c|c|c|c|c|}
\hline \multirow{2}{*}{ Materials } & \multicolumn{8}{|c|}{ Chemical composition /wt\% } & \multirow{2}{*}{$\begin{array}{c}\text { Densiy } \\
\mathrm{g} / \mathrm{cm}^{3}\end{array}$} & \multirow{2}{*}{$\begin{array}{l}\text { Specific } \\
\text { surface } \\
\mathrm{m}^{2} / \mathrm{Kg}\end{array}$} \\
\hline & $\mathrm{CaO}$ & $\mathrm{SiO}_{2}$ & $\mathrm{Al}_{2} \mathrm{O}_{3}$ & $\mathrm{Fe}_{2} \mathrm{O}_{3}$ & $\mathrm{MgO}$ & $\mathrm{K}_{2} \mathrm{O}$ & $\mathrm{Na}_{2} \mathrm{O}$ & $\mathrm{SO}_{3}$ & & \\
\hline Cement & 63.44 & 20.01 & 5.74 & 3.26 & 1.77 & 0.90 & 0.20 & 1.47 & 3.10 & 340 \\
\hline Steel slag & 40.23 & 18.78 & 3.67 & 21.19 & 7.53 & 0.04 & 0.15 & 0.25 & 3.51 & 455 \\
\hline Slag & 40.21 & 30.05 & 14.22 & 0.56 & 10.0 & 0.34 & 0.27 & 0.48 & 3.0 & 430 \\
\hline Fly ash & 6.78 & 47.6 & 29.6 & 6.61 & 1.14 & 1.35 & 0.47 & 0.81 & 2.40 & 425 \\
\hline
\end{tabular}
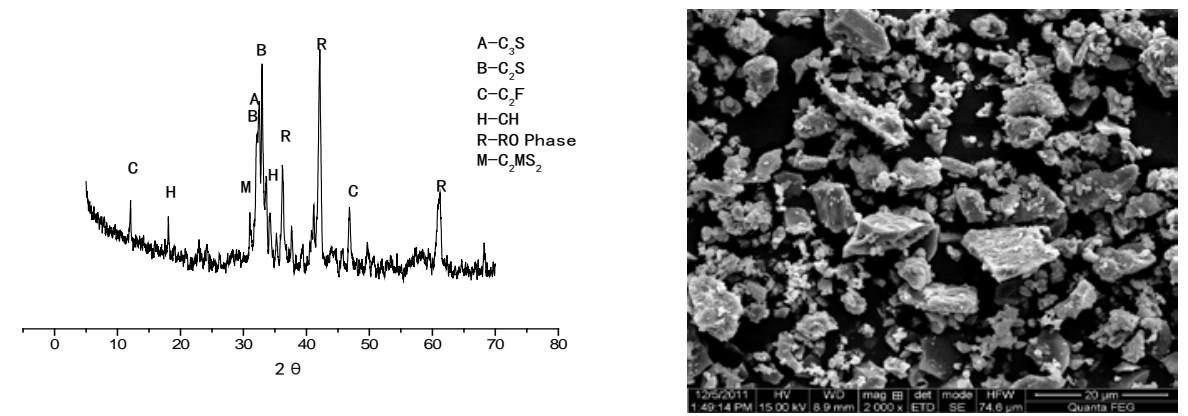

Fig.1 X- ray diffraction spectra of steel slag

Fig.2 SEM photo of steel slag

Table 2 composition of naphthalene series water reducer

\begin{tabular}{cccccc}
\hline Component & PPN-A & Sodium glucose & Sodium phosphate & Rosin & Water \\
\hline Content $/ \%$ & 76.57 & 0.598 & 0.0997 & 0.1994 & 22.53 \\
\hline
\end{tabular}

Experimental Method.

Table 3 Proportion of mineral admixture mixed with experiment and test results

\begin{tabular}{|c|c|c|c|c|c|c|}
\hline \multirow{2}{*}{ NO. } & \multicolumn{4}{|c|}{ Mineral admixture content /\% } & \multirow{2}{*}{$\begin{array}{c}\text { Cement } \\
\text { content } \\
/ \%\end{array}$} & \multirow{2}{*}{$\begin{array}{l}\text { Slump } \\
\text { /mm }\end{array}$} \\
\hline & Total & Steel slag & Slag & Fly ash & & \\
\hline A20 & \multirow{4}{*}{20} & 6.67 & 6.67 & 6.66 & \multirow{4}{*}{80} & 173 \\
\hline B20 & & 10 & 5 & 5 & & 176 \\
\hline C20 & & 5 & 10 & 5 & & 180 \\
\hline D20 & & 5 & 5 & 10 & & 169 \\
\hline A30 & \multirow{4}{*}{30} & 10 & 10 & 10 & \multirow{4}{*}{70} & 211 \\
\hline B30 & & 15 & 7.5 & 7.5 & & 215 \\
\hline C30 & & 7.5 & 15 & 7.5 & & 222 \\
\hline D30 & & 7.5 & 7.5 & 15 & & 207 \\
\hline A40 & \multirow{4}{*}{40} & 13.33 & 13.33 & 13.34 & \multirow{4}{*}{60} & 218 \\
\hline B40 & & 20 & 10 & 10 & & 225 \\
\hline C40 & & 10 & 20 & 10 & & 230 \\
\hline D40 & & 10 & 10 & 20 & & 210 \\
\hline A50 & \multirow{4}{*}{50} & 16.67 & 16.67 & 16.66 & \multirow{4}{*}{50} & 224 \\
\hline B50 & & 25 & 12.5 & 12.5 & & 233 \\
\hline C50 & & 12.5 & 25 & 12.5 & & 240 \\
\hline D50 & & 12.5 & 12.5 & 25 & & 220 \\
\hline
\end{tabular}

The dosage of the cement was $400 \mathrm{~kg} / \mathrm{m}^{3}$, the amount of the river sand was $738 \mathrm{~kg} / \mathrm{m}^{3}$, the gravel was $1108 \mathrm{~kg} / \mathrm{m}^{3}$, the water cement ratio was 0.4 , the effective water reducing admixture dosage was 
2\%; The ratio is shown in Table 3. Using cement and the best proportion of composite cementitious materials for preparing paste block, which was used for the microscopic test.

\section{Experimental Results and Discussion}

Effect of steel slag powder, slag powder and fly ash on the performance of concrete.

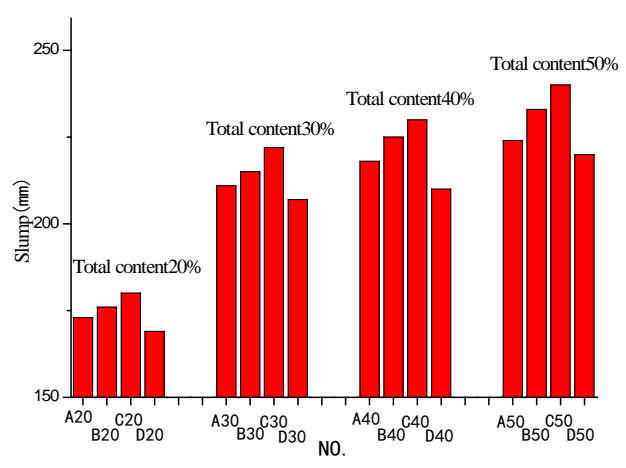

a. Slump

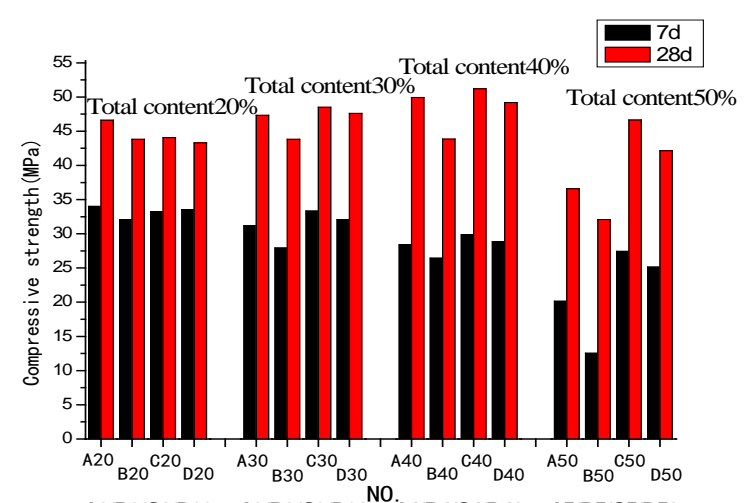

b. Compressive strength

Fig.3 Effect of steel slag powder, slag powder and fly ash on the performance of concrete

From Fig. 3(a), with mixed composite material content was increased, the slump of the concrete increases. Under a fixed total volume, than other ratios and in steel slag powder: slag powder: fly ash $=1: 2: 1$, on concrete slump degree of improvement was the most obvious, slag for concrete slump degree of improvement was the best, followed by steel slag and fly ash.

From Figure 3(b) we can see that, the $7 d$ compressive strength of concrete decreases gradually with the increase of the total content of composite admixture, and the change of 28d intensity was little. Also from Figure 3(b) showed that, under the same total volume, when the composite blending material steel slag powder: slag powder: fly ash $=1: 2: 1,7 \mathrm{~d}$ and $28 \mathrm{~d}$ strength of concrete were higher. The reason was mainly due to the low activity of mineral composite admixture, the early strength of concrete was mainly provided by cement [5]. Later, under the excitation of $\mathrm{Ca}(\mathrm{OH})_{2}$, mineral admixture gradually hydrolysis, produced hydrated calcium silicate, hydrated calcium aluminate, filled in the pores of concrete, and consumed the $\mathrm{Ca}(\mathrm{OH})_{2}[6]$.

In summary, the suitable dosage was $30 \% \sim 40 \%$, and the appropriate proportion of composite admixture was steel slag powder: slag powder: fly ash $=1: 2: 1$.

Effect of steel slag powder, slag powder and fly ash on hydration of cement.

1) XRD analysis of hydration products of cement and composite cementitious materials

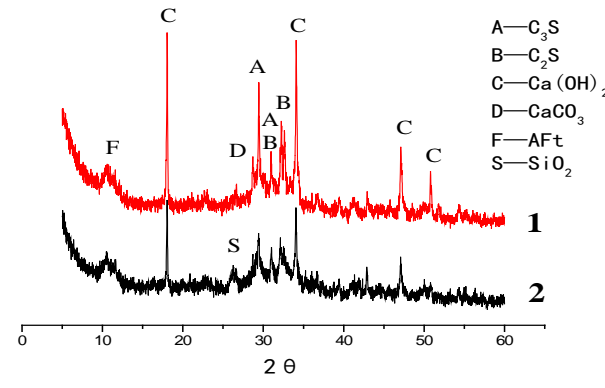

a. Hydration $7 d$

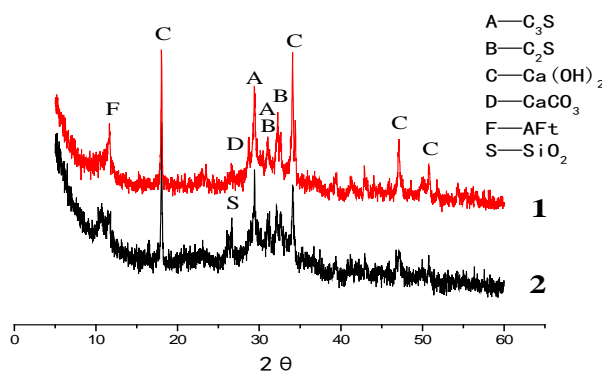

b. Hydration 28d

Fig.4 XRD patterns of 7d and 28d hydration products of cement and composite cementitious materials

Note: 1 is cement; 2 is a composite cementitious material

From Figure 4, the XRD patterns of the composite cementitious materials are basically the same as those of the pure cement hydration products, which contain $\mathrm{Ca}(\mathrm{OH})_{2}$, AFt, C-S-H gel (30 degree), $\mathrm{C}_{3} \mathrm{~S}$ and $\mathrm{C}_{2} \mathrm{~S}$ minerals. In addition, at the hydration of $7 \mathrm{~d}$ and $28 \mathrm{~d}$, the diffraction peak intensity of $\mathrm{Ca}(\mathrm{OH})_{2}, \mathrm{C}_{3} \mathrm{~S}$ and $\mathrm{C}_{2} \mathrm{~S}$ was significantly lower than that of the pure cement, this aspect is because of 
the content of cement is reduced by adding material, making $\mathrm{C}_{2} \mathrm{~S}$ and $\mathrm{C}_{3} \mathrm{~S}$ and other clinker mineral content and the formation of $\mathrm{Ca}(\mathrm{OH})_{2}$ reduction; On the other hand, slag powder, slag powder, fly ash of the "volcanic ash reaction" consumption of the system in the $\mathrm{Ca}(\mathrm{OH})_{2}$ crystal [10].

2) SEM analysis of hydration products of cement and composite cementitious materials

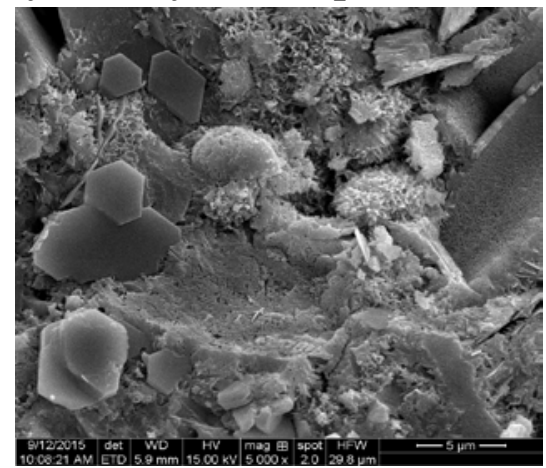

a. Cement hydration 7d

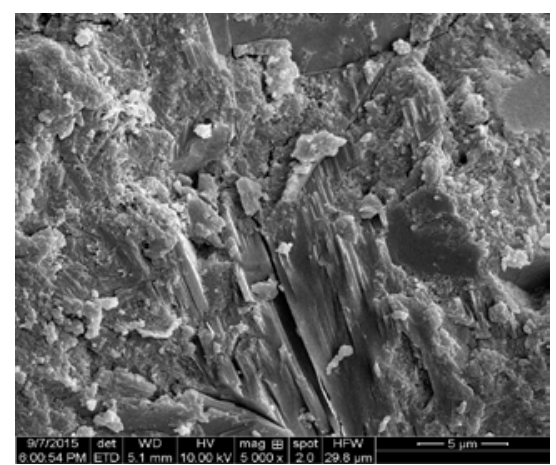

c. Cement hydration 28d

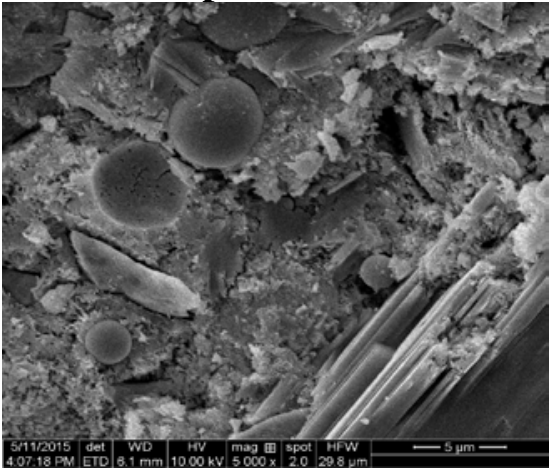

b. Composite cementitious material hydration $7 \mathrm{~d}$

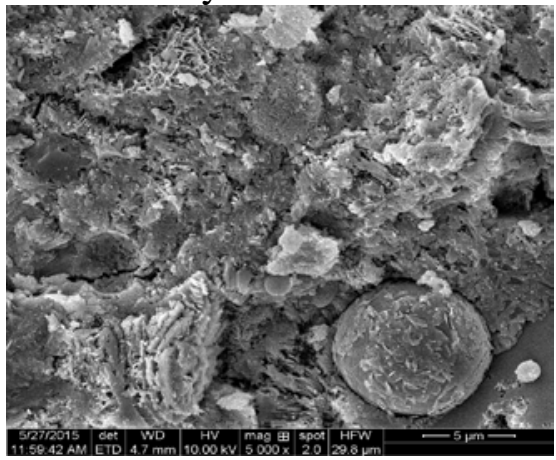

d. Composite cementitious material hydration 28d

Fig. 5 SEM images of 7d and 28d hydration products of cement and composite cementitious materials.

From figure 5, when hydration to 7d, the composite cementitious material of the hardened paste structure was loose, the steel slag powder, slag powder, fly ash were encapsulated by hydration products, but the surface was smooth. When hydration to 28d, pure cement paste structure was dense, but contains a large number of $\mathrm{Ca}(\mathrm{OH})_{2}$, would have a negative effect on the strength and durability of concrete; And at the same time, slag powder, slag powder, fly ash particle surface could significantly see the flocculent structure of the gel, and the $\mathrm{Ca}(\mathrm{OH})_{2}$ of hardened paste content decreased significantly and paste structure became dense. This indicated that under the excitation of $\mathrm{Ca}(\mathrm{OH})_{2}$, steel slag powder, slag powder and fly ash generated the hydration products [7], which can reduce the porosity of cement paste, increase the density of cement paste.

\section{3) DSC analysis of hydration products of cement and composite cementitious materials}

Fig.6(1 4) showed that the hydration products of composite cementitious materials with steel slag powder, slag powder and fly ash are basically the same as that of pure cement paste, which contained $\mathrm{Ca}(\mathrm{OH})_{2}$, AFt, C-S-H gel. At the DSC of hydration 7d, the early dehydration endothermic peak of AFt and C-S-H gels, the dehydration of $\mathrm{Ca}(\mathrm{OH})_{2}$ and the peak area of the late AFm, C-S-H gel decomposition endothermic peak was significantly lower than that of pure cement. When hydration to 28d, the peak area of the endothermic peak was basically the same as that of the pure cement, except for $\mathrm{Ca}(\mathrm{OH})_{2}$, it showed that the second hydration reaction of steel slag powder, slag powder and fly ash in $\mathrm{Ca}(\mathrm{OH})_{2}$ was described, generates C-S-H gel, and the results were consistent with the results of XRD analysis. 


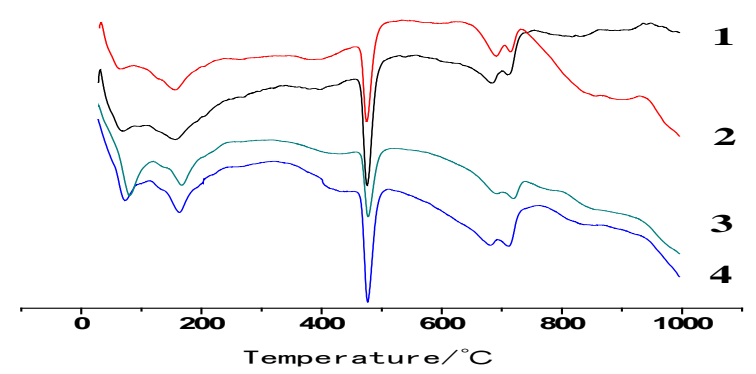

Fig. 6 DSC patterns of 7d and 28d hydration products of cement and composite cementitious materials.

Note: 1 is cement hydration 7d; 2 is the composite cementitious material hydration $7 d$;

3 is the composite cementitious material hydration 28d; 4 is cement hydration 28d.

\section{Summary}

In this paper, the effect of steel slag powder, slag powder and fly ash on the performance and mechanical properties of concrete were studied, and the corresponding microscopic analysis was carried out, and the main results were as follows:

(1)When the total amount of compound admixture was less than $40 \%$, the increase of the content of the composite was beneficial to improving the performance and mechanical properties of concrete. When the steel slag: slag powder: fly ash $=1: 2: 1$, could better play the "complementary effect", and show good post strength.

(2)The results of XRD analysis, SEM analysis and DSC analysis showed that the hydration products of composite cementitious materials were basically the same as that of pure cement paste.

(3) The early activity of steel slag powder, slag powder, fly ash was low, and after the excitation of $\mathrm{Ca}(\mathrm{OH})_{2}$, steel slag powder, slag powder, fly ash began to hydrolysis, the formation of hydrated calcium silicate, hydrated calcium aluminate make the hardened paste structure more dense.

\section{References}

[1]. ALTAN E, ERDOGAN S T. Alkali activation of a slag at ambient and elevated temperatures [J]. Cem Concr Compos. Vol. 34(2011) No. 11, p. 1-9.

[2]. CHEN W, BROUWERS H J H. The hydration of slag, part 1: reaction models for alkali-activated slag [J]. J Mater Sci. Vol. 42 (2007), p. 428-443.

[3]. LI Xiang, Aruhan, YAN Pei-yu. Research On Hydration Degree of Cement-Fly Ash Complex Binders [J]. Journal Of Building Materials. Vol. 13(2010) No. 5, p. 584-588.

[4]. Tufekci M, Demirbas A, Genc H. Evaluation of steel stags as cement additives[J]. Cement and concrete research. Vol. 27(1997) No. 11, p. 1713-1717.

[5]. Shen Weikai, Zhao Qinglin. Development of steel slag fly ash pavement base material[J]. Journal Of WuHan University Of Technology. Vol. 24(2002) No. 5, p. 15-18.

[6]. Zhu Wenqi, Zhu Jidong. Research on construction technology of steel slag asphalt mixture[J]. Journal Of WuHan University Of Technology. Vol. 25(2003) No. 12, p. 116-118.

[7]. Zhang Jinghong, Ding Hong, SunChao. Hydration products, microstructure and properties of slag and fly ash mixture[J]. Journal Of The Chinese Ceramic Society. Vol. 35(2007) No. 5, p. 633-637. 